\title{
PENGARUH STRATEGI PEMASARAN TERHADAP LOYALITAS KONSUMEN PADA GIANT SUPERMARKET (PT. HERO SUPERMARKET TBK) DI BANDAR LAMPUNG
}

\author{
Yudiana Sari, SE, MM \\ STIE SATU NUSA
}

\begin{abstract}
The object of this research is Giant Supermarket (PT Hero Supermarket Tbk) in Bandar Lampung. Giant is one of the largest retail networks in Indonesia. The problem studied was to find out the effect of marketing strategies on consumer loyalty at Giant Supermarket (PT. Hero Supermarket Tbk) in Bandar Lampung because of consumer loyalty at the Giant Supermarket (PT. Hero Supermarket Tbk) which declined. The research method used in this study is library research and field research conducted by directly examining Giant Supermarkets (PT Hero Supermarket Tbk) in Bandar Lampung related to marketing strategies and their influence on consumer loyalty at Giant Supermarket (PT. Hero Supermarket Tbk) in Bandar Lampung. The results showed that the matrix analysis of IFAS and EFAS resulted in an analysis of the company's internal factors in the marketing strategy of Giant Supermarket (PT Hero Supermarket Tbk) in Bandar Lampung, which became the main force, namely promotion carried out by the company with a total value of 0.4662 and the main disadvantage is that famous brands still dominate with a total value of 0.1200. While the company's external factors in the marketing strategy of PT Giant Supermarket (PT Hero Supermarket Tbk) in Bandar Lampung, which is the main opportunity, is an increase in the population with a total value of 0.4235 and the company's main threat is the number of competing companies with a total value of 0.1582. External internal matrix analysis (IE) Giant Supermarkets (PT Hero Supermarket Tbk) In Bandar Lampung are in the $V$ cell position, thus implementing a strategy of maintaining and maintaining consumers (high consumer loyalty).
\end{abstract}

Keywords: Strategy, Marketing, Loyalty, Consumers, IFAS, EFAS

\section{PENDAHULUAN}

\subsection{Latar Belakang}

Supermarket Modern disini adalah penataan barang menurut keperluan yang sama dikelompokkan dibagian yang sama yang dapat dilihat dan diambil langsung oleh pembeli, pramuniaga professional. Ritel modern pertama kali hadir di Indonesia saat Toserba Sarinah didirikan pada 1962. Pada era 1970 s/d 1980an, format bisnis ini terus berkembang. Awal dekade 1990-an merupakan tonggak sejarah masuknya ritel asing di Indonesia. Ini ditandai dengan beroperasinya ritel terbesar Jepang "Sogo" di Indonesia. Ritel modern kemudian berkembang begitu pesat saat pemerintah, berdasarkan Kepres no. 99 tahun 1998, mengeluarkan bisnis ritel dari negatif list bagi Penanaman Modal Asing. Sebelum Kepres no. 99 Th 1998 diterbitkan, jumlah peritel asing di Indonesia sangat dibatasi.

Strategi pemasaran ritel adalah pemasaran yang mengacu kepada variabel, dimana pedagang eceran dapat mengkombinasikan menjadi jalan alternatif sebagai suatu strategi pemasaran untuk dapat menarik konsumen. Variabel tersebut umumnya meliputi faktor seperti variasi barang dagangan dan jasa yang ditawarkan, harga, iklan, promosi, dan tata ruang, desain store, lokasi store dan merchanding. 
Untuk menjaga kelangsungan hidup serta kemajuan dan keunggulan dalam bisnis eceran yang semakin kompetitif, maka pengelola bisnis tersebut harus berupaya menerapkan strategi berupa program bauran penjualan eceran yang diharapkan memunculkan minat konsumen.

Kualitas pelayanan mencerminkan evaluasi persepsi konsumen tentang elemen-elemen jasa (kualitas interaksi, kualitas lingkungan fisik, dan kualitas hasil), kemudian elemen-elemen jasa akan dievaluasi berdasarkan dimensi kualitas pelayanan yang spesifik, antara lain kehandalan, daya tangkap, jaminan, kemudahan dalam melakukan hubungan, dan bukti langsung.

Loyalitas konsumen Giant

Supermarket (PT. Hero Supermarket Tbk)

Di Bandar Lampung adalah suatu pembelian ulang yang dilakukan oleh seorang pelanggan karena komitmen pada suatu merk atau Giant Supermarket (PT. Hero Supermarket Tbk) Di Bandar Lampung.

\section{TINJAUAN PUSTAKA}

1. Pemasaran

a. Pengertian Pemasaran

Pada saat ini kegiatan pemasaran mempunyai peranan yang sangat penting dalam dunia usaha. Kadang-kadang istilah pemasaran ini diartikan sama dengan beberapa istilah, seperti : penjualan, perdagangan dan distribusi. Salah pengertian ini timbul karena pihak-pihak yang bersangkutan mempunyai kegiatan dan kepentingan yang berbeda-beda. Menurut Basu Swastha dan Ibnu Sukotjo (2002) Pemasaran adalah sistem keseluruhan dari kegiatan usaha yang ditujukan untuk merencanakan, menentukan harga, mempromosikan, dan mendistribusikan barang dan jasa yang dapat memuaskan kebutuhan kepada pembeli yang ada maupun pembeli potensial.

Philip Kotlher dan Gary Amstrong (2004) mendefinisikan pemasaran sebagai proses sosial dan manajerial dimana individu dan kelompok memperoleh apa yang mereka butuhkan dan inginkan melalui penciptaan dan pertukaran produk serta nilai dengan pihak lain. Sedangkan menurut Freddy Rangkuti (2006) Pemasaran adalah suatu proses kegiatan yang dipengaruhi oleh berbagai faktor sosial, budaya, politik, ekonomi dan manajerial. Akibat pengaruh dari berbagai faktor tersebut adalah masing-masing individu maupun kelompok mendapatkan kebutuhan dan keinginan dengan menciptakan, menawarkan, dan menukarkan produk yang memiliki nilai komoditas.

b. Konsep Pemasaran

Philip Kotlher dan Gary Amstrong (2004) menyatakan bahwa terdapat lima konsep alternatif yang melandasi aktivitas pemasaran, yakni :

1) Konsep Produksi

Konsep produksi merupakan salah satu falasfah yang paling tua yang membimbing penjual. Konsep produski menyatakan bahwa pelanggan akan menyukai produk yang tersedia dan harganya terjangkau. Oleh karena itu manajemen harus berusaha keras untuk memperbaiki produksi dan efisiensi distribusi.

2) Konsep Produk

Konsep produk menyatakan bahwa konsumen akan menyukai produk yang mempunyai mutu terbaik, kinerja terbaik, dan sifat paling inovatif sehingga organiasai harus mencurahkan energi secara terus menerus melakukan perbaikan produk.

3) Konsep Penjualan

Konsep penjualan menyatakan bahwa konsumen tidak akan membeli produk suatu organisasi/perusahaan dalam jumlah cukup kecuali jika organisasi/ perusahaan tersebut melakukan penjualan dan promosi berskala besar.

4) Konsep Pemasaran

Konsep pemasaran menyatakan bahwa pencapaian sasaran organisasi tergantung pada penentuan kebutuhan dan keinginan pasar sasaran dan 
penyampaian kepuasan yang didambakan itu lebih efektif dan efisien dibandingkan pesaing.

5) Konsep Pemasaran Berwawasan Sosial. Konsep pemasaran berwawasan sosial menyatakan bahwa organisasi harus menentukan kebutuhan, keinginan, dan minat pasar sasaran. Konsep pemasaran berwawasan masyarakat merupakan yang terbaru dari kelima falsafah menajemen pemasaran.

c. Tujuan Pemasaran

Pemasaran, lebih berurusan dengan pelanggan dibandingkan fungsi bisnis lainnya. Kotler (2002:15) yang dikutip oleh Rahmat (2012) mengemukakan bahwa pemasaran mempunyai tujuan membangun hubungan jangka panjang yang saling memuaskan dengan pihakpihak yang memiliki kepentingan utama pelanggan, pemasok, distributor dalam rangka mendapatkan serta mempertahankan referensi dan kelangsungan bisnis jangka panjang mereka.

2. Strategi Pemasaran

a. Pengertian Strategi

Strategi merupakan alat untuk mencapai tujuan. Dalam perkembangannya, konsep mengenai strategi terus berkembang. Berikut ini merupakan definisi strategi menurut beberapa ahli yang dikutip oleh Freddy Rangkuti (2006) : Strategi merupakan alat untuk mencapai tujuan perusahaan dalam kaitannya dengan tujuan jangka panjang, program tindak lanjut, serta prioritas alokasi sumber daya. Learned, Christensen, Andrews, dan Guth (2006): Strategi merupakan alat untuk menciptakan keunggulan bersaing. Dengan demikian salah satu fokus strategi adalah memutuskan apakah bisnis tersebut harus ada atau tidak ada.

b. Pengertian Strategi Pemasaran

Strategi pemasaran pada dasarnya adalah rencana yang menyeluruh terpadu dan menyatu dibidang pemasaran yang memberikan panduan tentang kegiatan yang dijalankan dan tercapainya tujuan pemasaran serta menjadi hal yang paling fundamental bagi perusahaan (Sofyan dalam Syam, 2014). Menurut Fandy Tjiptono (2000:43) dalam Rahmat (2012) menyatakan bahwa strategi pemasaran adalah rencana yang hendak diikuti oleh manajer pemasaran.

c. Jenis-jenis Strategi Pemasaran Dalam hubungan strategi pemasaran, menurut Sofyan Assauri (2008:179) yang dikutip oleh Rahmat (2012) bahwa strategi pemasaran secara umum dapat dibedakan menjadi tiga jenis strategi pemasaran yang dapat ditempuh perusahaan yaitu:

1) Strategi pemasaran yang tidak membeda-bedakan pasar (Undifferentiated marketing)

2) Strategi pemasaran yang membedabedakan pasar (Differentiated marketing).

3) Strategi pemasaran yang terkonsentrasi (Concentrated marketing)

\section{Strategi Bauran Pemasaran (Marketing Mix)}

Bauran pemasaran didefinisikan oleh Philip Kotlher dan Gary Amstrong (2004) sebagai seperangkat alat pemasaran taktis yang dapat dikendalikan, yang dipadukan oleh perusahaan untuk menghasilkan tanggapan yang diinginkan dalam pasar sasaran. Sedangkan Suliyanto (2010) mendefinisikan bauran pemasaran merupakan kombinasi dari empat variabel , empat kelompok utama yang dikenal dengan 4P, yaitu (1) Product (produk), (2) Price (harga), (3) Promotion (promosi), dan (4) Place (tempat/distribusi).

\section{Analisis SWOT}

Menurut Freddy Rangkuti (2006), analisis SWOT adalah identitas berbagai faktor secara sistematis untuk merumuskan strategi perusahaan. Analisis ini berdasarkan logika yang dapat memaksimalkan kekuatan (strength) dan peluang (opportunity), namun secara 
bersamaan dapat meminimalkan kelemahan (weaknesses) dan ancaman (treath). Hal ini disebut dengan analisis situasi. Model yang paling popular untuk analisis situasi adalah Analisis SWOT. Analisis SWOT membandingkan antara faktor eksternal dan faktor internal. Diagram analisis SWOT:



Gambar. 1 Diagram Analisis SWOT

Sumber : Freddy Rangkuti, 2009

Fungsi dari Analisis SWOT adalah untuk mendapatkan informasi dari analisis situasi dan memisahkannya dalam pokok persoalan internal (kekuatan dan kelemahan) dan pokok persoalan eksternal (peluang dan ancaman).

\section{a. Matriks Faktor Strategi Eksternal}

Sebelum membuat matriks faktor strategi eksternal, kita perlu mengetahui terlebih dahulu Faktor Strategi Eksternal (EFAS). Berikut ini adalah cara-cara penentuan Faktor Strategi Eksternal (EFAS) :

1) Susunlah dalam kolom1 (5 sampai dengan 10 peluang dan ancaman).

2) Beri bobot masing-masing factor dalam kolom 2, mulai dari 1,0 (sangat penting) sampai dengan 0,0 (tidak penting).

3) Hitung rating (dalam kolom 3) untuk masing-masing factor dengan memberikan skala mulai dari 4 (outstanding) sampai dengan 1 (poor) berdasarkan pengaruh faktor tersebut terhadap kondisi perusahaanyang bersangkutan.

4) Kalikan bobot pada kolom 2 dengan rating pada kolom 3 , untuk memperoleh factor pembobotan dalam kolom 4 . Hasilnya berupa skor pembobotan untuk masing-masing faktor yang nilainya bervariasi mulai dari 4,0 (outstanding) sampai dengan 1,0 (poor).

5) Gunakan kolom 5 untuk memberikan komentar atau catatan mengapa faktorfaktor tersebut dipilih dan bagaimana skor pembobotannya dihitung.

6) Jumlahkan skor pembobotan (pada kolom 4), untuk memperoleh total skor pembobotan bagi perusahaan yang bersangkutan.

Faktor-Faktor Strategi Eksternal

Peluang:

1) Integrasi ekonomi Eropa

2) Perubahan struktur demografi

3) Pembangunan ekonomi di Asia

4) Terbukanya Eropa Timur

5) Kecenderungan superstores

Ancaman :

1) Meningkatnya peraturan pemerintah

2) Meningkatnya persaingan

b. Matriks Faktor Strategi Internal

Setelah faktor-faktor strategi internal perusahaan diidentifikasikan, suatu tabel IFAS (Internal Factors Analysis Summary) disusun untuk merumuskan faktor-faktor strategi internal tersebut dalam kerangka 
Strenght and Weakness perusahaan.

Tahapnya adalah :

1) Tentukan faktor-faktor yang menjadi kekuatan serta kelemahan perusahaan dalam kolom 1.

2) Beri bobot masing-masing factor tersebut dengan skala mulai dari 1,0 (paling penting) sampai dengan 0,0 (tidak penting), berdasarkan pengaruh faktor-faktor tersebut terhadap posisi strategis perusahaan. (Semua bobot tersebut jumlahnya tidak boleh melebihi skor total 1,00).

3) Hitung rating (dalam kolom 3) untuk masing-masing faktor dengan memberikan skala mulai dari 4 (outstanding) sampai dengan 1 (poor), berdasarkan pengaruh faktor tersebut terhadap kondisi perusahaan yang bersangkutan. Variabel yang bersifat positif (semua variabel yang masuk kategori kekuatan) diberi nilai+1 sampai dengan +4 (sangat baik) dengan membandingkan rata-rata industri atau dengan pesaing utama.

4) Kalikan bobot pada kolom 2 dengan rating pada kolom 3, untuk memperoleh faktor pembobotan dalam kolom 4 . Hasilnya berupa skor pembobotan untuk masing-masing faktor yang nilainya bervariasi mulai dari 4,0 (outsanding) sampai 0,0 (poor).

5) Gunakan kolom 5 untuk memberikan komentar atau catatan mengapa faktorfaktor tertentu dipilih dan bagaimana skor pembobotan dihitung.

6) Jumlahkan skor pembobotan (pada kolom 4), untuk memperoleh total skor pembobotan bagi perusahaan yang bersangkutan.

Faktor-Faktor Strategi Eksternal

Kekuatan:

1) Budaya kualitas Maytag

2) Pengalaman Top Manager

3) Integrasi vertical

4) Hubungan yang baik dengan SDM

5) Memiliki orientasi intenasional

Kelemahan :

1) Proses produksi (R\&D)

2) Saluran distribusi

3) Dukungan kondisi keuangan kurang begitu baik

4) Posisi global sangat kurang

c. Fasilitas manufakturMatriks TOWS atau SWOT

Salah satu metode atau alat analisis yang digunakan untuk menyusun deskripsi tentang faktor-faktor strategi perusahan adalah SWOT Matrix. Matrikss kini dapat menghasilkan empat kemungkinan alternative strategi.

Tabel 1.Matriks SWOT

\begin{tabular}{|c|c|c|}
\hline EFAS & $\begin{array}{c}\text { Strengths }(S) \\
\\
\text { Tentukan 5-10 } \\
\text { Faktor-Faktor } \\
\text { Kekuatan Internal } \\
\end{array}$ & $\begin{array}{c}\text { Weaknesses }(\boldsymbol{W}) \\
\text { Tentukan 5-10 } \\
\text { Faktor-Faktor } \\
\text { Kelemahan Internal }\end{array}$ \\
\hline $\begin{array}{c}\text { Opportunities }(O) \\
\text { Tentukan 5-10 Faktor- Faktor } \\
\text { Peluang Eksternal }\end{array}$ & $\begin{array}{c}\text { Strategi SO } \\
\text { Ciptakan strategi yang } \\
\text { menggunakan kekuatan untuk } \\
\text { memanfaatkan peluang }\end{array}$ & $\begin{array}{c}\text { Strategi WO } \\
\text { Ciptakan strategi yang } \\
\text { meminimalkan kelemahan untuk } \\
\text { memanfaatkan peluang }\end{array}$ \\
\hline $\begin{array}{c}\text { Treaths(T) } \\
\text { Tentukan 5-10 Faktor- Faktor } \\
\text { Ancaman Eksternal }\end{array}$ & $\begin{array}{c}\text { StrategiST } \\
\text { Ciptakan strategi yang } \\
\text { menggunakan kekuatan untuk } \\
\text { mengatasi ancaman }\end{array}$ & $\begin{array}{c}\text { StrategiWT } \\
\text { Ciptakan strategi yang } \\
\text { meminimalkan kelemahan dan } \\
\text { menghindari ancaman }\end{array}$ \\
\hline
\end{tabular}

Sumber:Fredy Rangkuti(2009:31)

Keterangan :
1. EFAS = Eksternal Strategic Factor Analysis

2. IFAS = Internal Strategic Factor Analysis

3. Strategi SO, Memanfaatkan seluruh 
kekuatan untuk merebut dan memanfaatkan peluang sebesarbesarnya

4. Strategi ST, Menggunakan kekuatan untuk mengatasi ancaman

5. Strategi WO, Strategi ini diterapkan berdasarkan pemanfaatan peluang yang ada dengan meminimalkan kelemahan.

6. Strategi WT, Bersifat defensif dan berusaha meminimalkan kelemahan yang ada serta menghindari ancaman.

\section{METODOLOGI PENEITIAN}

Penulis menggunakan dua metode penelitian untuk mendapatkan data, yaitu:

1. Penelitian Kepustakaan

2. Penelitian Lapangan

Dilakukan dengan meneliti langsung pada melalui metode wawancara dan penyebaran kuesioner yang berkaitan dengan strategi pemasaran terhadap loyalitas konsumen Giant Supermarket (PT. Hero Supermarket Tbk) Di Bandar Lampung.

\section{HASIL DAN PEMBAHASAN}

1. Matriks Faktor Strategi Internal

Analisis matriks IFAS merupakan hasil dari identifikasi faktor internal berupa kekuatan (strength) dan kelemahan (weakness) yang berpengaruh terhadap Giant Supermarket Di Bandar Lampung. Hasil identifikasi faktor-faktor strategi internal diperoleh 7 faktor kekuatan dan 4 faktor kelemahan. Faktor-faktor tersebut diberi nilai bobot dan rating oleh para responden. Hasil analisis matriks IFAS dapat dilihat pada Tabel 2.

Tabel 2. Matriks IFAS Giant Supermarket Di Bandar Lampung

\begin{tabular}{|c|c|c|c|c|}
\hline No & Faktor-Faktor Strategi Internal & Bobot & Rating & Bobot x Rating \\
\hline \multicolumn{5}{|c|}{ Kekuatan } \\
\hline 1 & Visi dan Misi Perusahaan & 0.072 & 3.4 & 0.2448 \\
\hline 2 & Jaringan Distribusi yang Luas & 0.118 & 3.7 & 0.4366 \\
\hline 3 & Kualitas dan Loyalitas SDM & 0.086 & 3.1 & 0.2666 \\
\hline 4 & Segmentasi Pasar yang Jelas & 0.099 & 3.4 & 0.3366 \\
\hline 5 & Kualitas Produk Yang Tersedia & 0.093 & 3.5 & 0.3255 \\
\hline 6 & $\begin{array}{l}\text { Sarana dan Prasarana Operasional } \\
\text { Perusahaan yang Memadai }\end{array}$ & 0.075 & 3.6 & 0.2700 \\
\hline 7 & Promosi yang Dilakukan Perusahaan & 0.126 & 3.7 & 0.4662 \\
\hline \multicolumn{5}{|c|}{ Kelemahan } \\
\hline 1 & $\begin{array}{l}\text { Pengembangan dan Inovasi Produk Yang } \\
\text { Tersedia }\end{array}$ & 0.071 & 1.5 & 0.1065 \\
\hline 2 & Kapasitas Produksi Masih Terbatas & 0.069 & 1.6 & 0.1104 \\
\hline 3 & Brand Terkenal Masih Mendominasi & 0.100 & 1.2 & 0.1200 \\
\hline 4 & Brand Image Konsumen & 0.091 & 1.3 & 0.1183 \\
\hline \multicolumn{2}{|c|}{ Total } & 1.000 & & 2.8015 \\
\hline
\end{tabular}

Sumber : Giant Supermarket (PT. Hero Supermarket Tbk) Di Bandar Lampung, 2018 
Berdasarkan Tabel 2 di atas dapat diketahui bahwa total nilai untuk faktorfaktor strategi internal sebesar 2,8015. Tabel IFAS di atas juga menunjukkan kekuatan utama pada Giant Supermarket (PT. Hero Supermarket Tbk) Di Bandar Lampung adalah promosi yang dilakukan perusahaan dengan total nilai 0,4662 selanjutnya diikuti jaringan distribusi yang luas dengan total nilai 0,4366. Faktor kelemahan utama pada Giant Supermarket (PT. Hero Supermarket Tbk) Di Bandar Lampung adalah brand terkenal masih mendominasi dengan total nilai 0,1200 selanjutnya diikuti brand image konsumen dengan total nilai 0,1183 .

2. Matriks Faktor Strategi Eksternal

Tabel 3. Matriks EFAS Giant Supermarket (PT. Hero Supermarket Tbk) Di Bandar Lampung

\begin{tabular}{|c|c|c|c|c|}
\hline No & Faktor-Faktor Strategi Eksternal & Bobot & Rating & Bobot $\mathrm{x}$ Rating \\
\hline \multicolumn{5}{|c|}{ Peluang } \\
\hline 1 & Peningkatan Jumlah Penduduk & 0.121 & 3.5 & 0.4235 \\
\hline 2 & Perkembangan Teknologi dan Komunikasi & 0.099 & 3.7 & 0.3663 \\
\hline 3 & $\begin{array}{l}\text { Potensi Industri Supermarket yang Masih } \\
\text { Besar }\end{array}$ & 0.089 & 3.7 & 0.3293 \\
\hline 4 & Pangsa Pasar Masih Luas & 0.114 & 3.7 & 0.4218 \\
\hline 5 & $\begin{array}{l}\text { Pertumbuhan Ekonomi yang Cepat di Negara- } \\
\text { Negara Asia dan Malaysia, Singapura, Jepang, } \\
\text { Cina }\end{array}$ & 0.094 & 3.3 & 0.3102 \\
\hline 6 & $\begin{array}{l}\text { Tingginya Loyalitas Konsumen terhadap } \\
\text { Produk Giant Supermarket (PT. Hero } \\
\text { Supermarket Tbk) Di Bandar Lampung }\end{array}$ & 0.086 & 3.3 & 0.2838 \\
\hline \multicolumn{5}{|c|}{ Ancaman } \\
\hline 1 & Banyaknya Perusahaan Pesaing & 0.113 & 1.4 & 0.1582 \\
\hline 2 & Adanya Produk Subtitusi & 0.088 & 1.6 & 0.1408 \\
\hline 3 & Persaingan Harga & 0.110 & 1.3 & 0.1430 \\
\hline 4 & Fluktuasi Nilai Tukar Rupiah & 0.086 & 1.6 & 0.1376 \\
\hline \multicolumn{2}{|r|}{ Total } & 1.000 & & 2.7145 \\
\hline
\end{tabular}

Sumber : Giant Supermarket (PT. Hero Supermarket Tbk) Di Bandar Lampung, 2018

Berdasarkan Tabel 3. di atas dapat diketahui bahwa total nilai untuk faktorfaktor strategi eksternal sebesar 2.7145 . Tabel EFAS di atas juga menunjukkan peluang utama pada Giant Supermarket (PT. Hero Supermarket Tbk) Di Bandar Lampung adalah peningkatan jumlah penduduk dengan total nilai 0,4235 selanjutnya diikuti pangsa pasar masih luas dengan total nilai 0,4218 . Faktor ancaman utama pada Giant Supermarket (PT. Hero Supermarket Tbk) Di Bandar Lampung adalah banyaknya perusahaan pesaing dengan total nilai 0,1582 selanjutnya diikuti persaingan harga Supermarket dengan total nilai 0,1430 .

3. Matriks Internal Eksternal

Matriks IE digunakan sebagai parameter untuk menganalisis posisi perusahaan secara lebih detail dan melihat strategi apa yang tepat untuk diterapkan oleh perusahaan. Berdasarkan matriks IFAS dan matriks EFAS dengan total nilai faktor strategi internal sebesar 2,8015 dan 
total nilai faktor strategi eksternal sebesar 2.7145 menunjukkan posisi Giant Supermarket (PT. Hero Supermarket Tbk) Di Bandar Lampung berada pada sel V. PT.
Hero Supermarket Tbk) Di Bandar Lampung adalah strategi penetrasi pasar, pengembangan pasar dan produk.

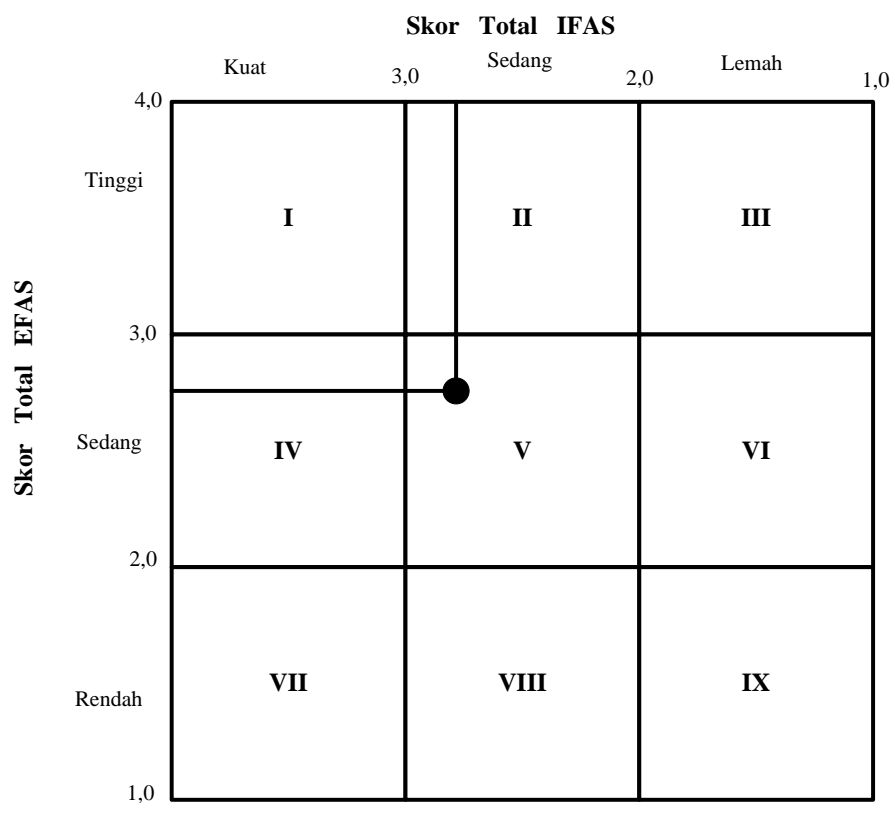

Gambar 2. Matriks Internal dan Eksternal Giant Supermarket (PT. Hero Supermarket Tbk) Di Bandar Lampung 65

Sumber : Giant Supermarket (PT. Hero Supermarket Tbk) Di Bandar Lampung, 2018

Berdasarkan matriks internal dan eksternal (IE) di atas, menunjukkan kondisi perusahaan berada di sel 5. Pada posisi tersebut perusahaaan dapat menerapkan strategi menjaga dan mempertahankan. Strategi yang dapat diterapkan oleh Giant Supermarket (PT. Hero Supermarket Tbk) Di Bandar Lampung adalah strategi penetrasi pasar dengan pengembangan pasar dan produk, menciptakan inovasi produk yang baru dan tetap menjaga atau meningkatkan kualitas produk yang sudah ada. Strategi ini merupakan strategi umum yang tidak memiliki implementasi strategi yang lebih teknis pada tingkat perusahaan.. Tujuannya relatif lebih defensif, yaitu menghindari kehilangan penjualan dan kehilangan profit, dimana perusahaan dapat mengembangkan teknologi dan memperluas pasar melalui perkembangan
Matriks SWOT dapat menggambarkan dengan jelas bagaimana strategi pemasaran perusahaan yang sesuai berdasarkan kekuatan dan kelemahan yang dimiliki dalam rangka merespon peluang dan ancaman yang ada. Berdasarkan analisis matriks EFAS dan IFAS menunjukkan bahwa untuk faktor-faktor Opportunity nilai skornya 2,1349 dan faktor Threat nilai skornya 0.5796, sedangkan Strength nilai skornya 2,3463 dan Weakness nilai skornya 0.4552. Maka diketahui nilai Strength diatas nilai Weakness selisih (+)1.8911 dan nilai Opportunity diatas nilai Threat selisih (+) 1.5553. Dari hasil identifikasi factor-faktor tersebut maka dapat digambarkan dalam Diagram SWOT, dapat dilihat pada gambar 3 


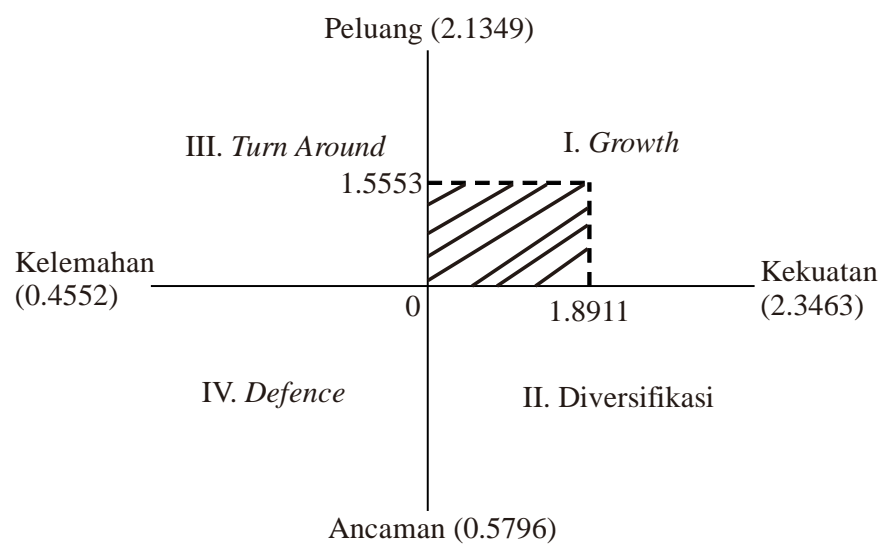

Gambar 3. Diagram Cartesisus Hasil Pengolahan Data Internal dan Eksternal Giant Supermarket (PT. Hero Supermarket Tbk) Di Bandar Lampung

Sumber : Giant Supermarket (PT. Hero Supermarket Tbk) Di Bandar Lampung, 2018

Berdasarkan gambar diagram cartesius diatas, sangat jelas menunjukkan bahwa Giant Supermarket (PT. Hero Supermarket Tbk) Di Bandar Lampung telah berada pada jalur yang tepat dengan terus melakukan strategi pengembangan (growth) yang dapat meningkatkan penjualan. Analisis matriks akan menghasilkan empat jenis strategi utama yaitu strategi S-O, W-O, S-T, dan W-T. Hasil dari analisis matriks SWOT pada Giant Supermarket (PT. Hero Supermarket Tbk) Di Bandar Lampung dapat dilihat pada Tabel 4. 
Tabel 4. Matriks SWOT Giant Supermarket (PT. Hero Supermarket Tbk)

Di Bandar Lampung

\begin{tabular}{|c|c|c|}
\hline EFAS & 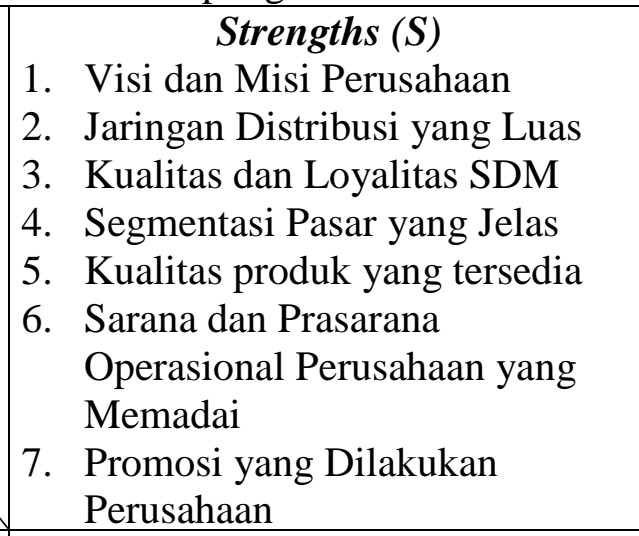 & \begin{tabular}{|l} 
Weaknesses $(\boldsymbol{W})$ \\
1. \\
Pengembangan dan \\
Inovasi Produk Yang \\
Tersedia \\
2. \\
Kapasitas Produksi \\
Masih Terbatas \\
3. \\
Brand Terkenal Masih \\
Mendominasi \\
4. \\
Brand Image \\
Konsumen
\end{tabular} \\
\hline 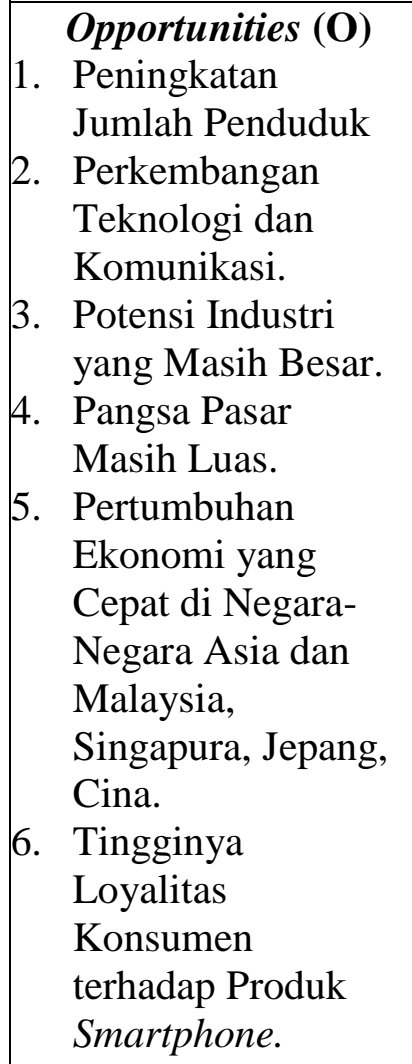 & \begin{tabular}{|l}
\multicolumn{1}{|c}{ Strategi S-O } \\
1. \\
Mempertahankan dan \\
meningkatkan kualitas produk \\
serta jaringan distribusi yang luas \\
untuk meningkatkan kepuasan \\
dan loyalitas konsumen. \\
2. Meningkatkan perkembangan \\
teknologi \\
3. Menjalin kerjasama dengan agen \\
distributor yang potensial untuk \\
menambah pangsa pasar.
\end{tabular} & \begin{tabular}{|l}
\multicolumn{1}{c}{ Strategi W-O } \\
1. \\
Meningkatkan jumlah \\
produk yang tersedia \\
sesuai dengan \\
permintaan konsumen. \\
2. \\
Mengembangkan \\
pangsa pasar yang luas \\
untuk meningkatkan \\
brand image \\
konsumen.
\end{tabular} \\
\hline  & \begin{tabular}{ll}
\multicolumn{1}{c}{ Strategi S-T } \\
1. & $\begin{array}{l}\text { Mengembangkan strategi } \\
\text { bersaing. }\end{array}$ \\
2. & Meningkatkan, dan \\
mengembangkan, serta \\
mempertahankan strategi \\
promosi yang dilakukan.
\end{tabular} & 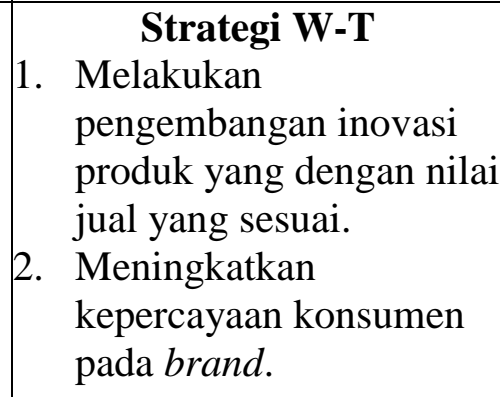 \\
\hline
\end{tabular}

Sumber : Giant Supermarket (PT. Hero Supermarket Tbk) Di Bandar Lampung, 2018

Alternatif Strategi Pemasaran

1. Strategi S-O (Strength-Opportunities)
Strategi ini dibuat berdasarkan jalan pikiran perusahaan. Strategi ini adalah untuk memanfaatkan seluruh kekuatan 
untuk merebut dan memanfaatkan peluang sebesar-besarnya. Strategi yang dapat digunakan yaitu pertama, mempertahankan dan meningkatkan kualitas produk serta jaringan distribusi yang luas untuk meningkatkan kepuasan dan loyalitas konsumen. Kedua, meningkatkan perkembangan teknologi. Ketiga, menjalin kerjasama dengan agen distributor yang potensial untuk menambah pangsa pasar.

2. Strategi S-T (Strength-Treath)

Strategi ini adalah untuk menggunakan kekuatan yang dimiliki perusahaan untuk mengatasi ancaman. Dalam hal ini perusahaan dapat mengembangkan strategi-strateginya. Strategi yang dapat digunakan yaitu pertama, dengan mengembangkan strategi bersaing. Kedua, meningkatkan dan mengembangkan, serta mempertahankan strategi promosi yang dilakukan.

3. Strategi W-O (WeaknessesOpportunities)

Strategi ini diterapkan berdasakan pemanfaatan peluang yang ada dengan cara meminimalkan kelemahan yang ada.

4. Strategi W-T (Weaknesses- Treath)

Strategi ini didasarkan pada kegiatan perusahaan yang bersifat defensif dan berusaha meminimalkan kelemahan yang ada serta menghindari ancaman. Strategi yang dapat dilakukan yaitu pertama, melakukan pengembangan inovasi produk yang dengan nilai jual yang sesuai. Kedua, meningkatkan kepercayaan dan loyalitas konsumen konsumen pada brand. .

\section{KESIMPULAN}

Berdasarkan hasil penelitian yang telah dilakukan melalui analisis lingkungan internal dan eksternal (matriks IFAS dan EFAS), analisis matriks IE, dan analisis SWOT pada pemasaran produk yang tersedia pada PT Giant Supermarket (PT. Hero Supermarket Tbk) Di Bandar
Lampung, maka dapat diambil beberapa kesimpulan sebagai berikut:

1. Analisis matriks IFAS dan EFAS, menghasilkan analisis faktor-faktor internal perusahaan dalam strategi pemasaran Giant Supermarket (PT. Hero Supermarket Tbk) Di Bandar Lampung, yang menjadi kekuatan utama, yaitu promosi yang dilakukan perusahaan dengan total nilai 0,4662 dan kelemahan utama adalah brand terkenal masih mendominasi dengan total nilai 0,1200 . Sedangkan faktorfaktor eksternal perusahaan dalam strategi pemasaran PT Giant Supermarket (PT. Hero Supermarket Tbk) Di Bandar Lampung yang menjadi peluang utama adalah peningkatan jumlah penduduk dengan total nilai 0,4235 dan ancaman utama perusahaan adalah banyaknya perusahaan pesaing dengan total nilai 0,1582 .

2. Analisis matriks internal eksternal (IE) Giant Supermarket (PT. Hero Supermarket Tbk) Di Bandar Lampung berada pada posisi sel $\mathrm{V}$, sehingga menerapkan strategi menjaga dan mempertahankan konsumen (loyalitas konsumen tinggi).

3. Analisis matriks SWOT menghasilkan beberapa alternatif strategi, antara lain yaitu mempertahankan dan meningkatkan kualitas produk serta jaringan distribusi yang luas untuk meningkatkan kepuasan dan loyalitas konsumen, meningkatkan perkembangan teknologi, mengembangkan strategi bersaing, juga meningkatkan, dan mengembangkan, serta mempertahankan strategi promosi yang dilakukan.

\section{DAFTAR PUSTAKA}

[1] Freddy Rangkuti. Analisis SWOT: Teknik Membedah Kasus Bisnis (Gramedia Pustaka Utama, 2008, 15th Edition) 
[2] Griffin, Jill. 2005. Customer Loyalty: Menumbuhkan dan Mempertahankan Kesetiaan Pelanggan. Alih bahasa : Dwi Kartini Yahya dan kawan kawan. Jakarta: Erlangga.

[3] Handoko, T. Hani. 2006. Manajemen Personalia Dan Sumber Daya Manusia. BPFE. Yogyakarta.

[4] Hasibuan, Malayu S P. 2000. Manajemen Sumber Daya Manusia. Bumi Aksara. Jakarta.

[5] Hayes, Bob E. 2008. The True Test Of Loyalty. Quality Progress Magazine, Vol. 6, No. 41, pg. 20.
[6] Hypermarket Strategies. International journal of Management and Marketing Research, Vol.2, No.1, pp.17-34.

[7] Kotler \& Amstrong. 2001. PrinsipPrinsip Pemasaran Jilid I. Penerbit PT. Prehalindo. Jakarta

[8] Swastha, Basu. 2002. Manajemen Penjualan: Pelaksanaan Penjualan, BPFEYogyakarta

[9] Tjiptono. Fandy. 2008. Strategi Pemasaran. ANDI. Yogyakarta 